\title{
Development of Science Comic Media Based on Local Culture Wisdom to Improve HOTS
}

\author{
Tri Widiyastuti ${ }^{1}$, Sty Slamet ${ }^{2}$, and Sandra Bayu Kurniawan ${ }^{3}$ \\ 1,2,3 Faculty of Teacher Training and Education, Universitas Sebelas Maret, Indonesia \\ Email: triwidiyastuti14@gmail.com
}

\begin{abstract}
We conducted this research because the teacher only uses lectures, books that have been provided by the government, and student worksheets. The purpose of this study was to determine the benefits of using instructional media in elementary schools to produce comic media based on local wisdom that can improve higher-order thinking skills, and can determine the feasibility of local wisdom-based comic media. This research is development research based on the Borg and Gall development model but is limited to the fifth stage, namely: (1) research and data collection, (2) planning, (3) product draft development, initial field trials, (5) revising trial results. The test subjects in this study were 33 students of class IV SDN 01 Sambirejo Jumantono District, Karanganyar Regency with details: 6 students for limited trials, and 27 students for field trials. The results showed that: (1) the provision of instructional media facilities in elementary schools which were the subject of the trial was not optimal, (2) the developed comic media in terms of the quality of media aspects and material aspects according to experts, according to the teacher, and the results of student responses were categorized very good, (3) comic media based on local wisdom is valid and can be tested in learning the theme of Peduli terhadap makhluk hidup, sub-theme Ayo Cintai Lingkungan in elementary schools. Comic media affects students' abilities in learning to improve higher-order thinking skills
\end{abstract}

Keywords: Science comic media, Local Culture, HOTS

\section{INTRODUCTIONS}

Social Sciences (IPS) is one of the compulsory subjects in elementary schools. This subject contains subjects related to social life. With the existence of social studies lessons in elementary schools is expected that students can have knowledge about the basic concepts of social science, sensitivity to social problems in their environment, and the role of humans as social creatures, so that IPS is not only mastering a collection of knowledge in the form of facts, concepts, or only principles but also a process of discovery. The learning process emphasizes providing direct experience to develop competencies to explore and understand the nature around scientifically.

But based on observations at school, the implementation of social studies learning found that students are only crammed with concepts without any scientific process to find these concepts. It is also exacerbated by social studies textbooks as supporting learning that contains material with little scientific activity involving students and the language used is too difficult for students to understand and also without the use of instructional media.

In reality, in the field, there are still many teachers who do not develop their creativity to plan, compile, and develop innovative and attractive learning media for students. Many educators still use conventional learning media, such as whiteboards and whiteboards, or instant learning media, just buy and use them like wall pictures, posters, and maps. This has an impact on decreasing teacher creativity and affects students' interest in learning. It is very possible that the learning media they use are not contextual, less attractive, seem monotonous, and do not match the needs of students.

The researcher conducted field observations and interviews with the fourth-grade teacher of SDN 01 Sambirejo Jumantono Karanganyar. Based on the results of the interview, information was obtained that teachers still experience problems in implementing learning using learning media in the classroom. The learning activities carried out only use textbooks for 
students and teacher handbooks that are distributed by the government. Regarding the use of media, the teacher admits that in learning, they have never used innovative learning media. SDN 01 Sambirejo Jumantono already has LCD projectors, but teachers have not used them optimally because they are still constrained by the use and preparation of computerbased learning materials. Only a few teachers can operate computers well. The teacher acknowledges that the existence of learning media is very important to foster student interest and streamline the learning process. Many factors were expressed by the teachers regarding constraints in media development, including factors of willingness, time, cost, and creativity.

Starting from the results of observations and interviews that have been conducted, this is a serious problem and a solution should be found immediately. One of them, teachers need to foster their will and creativity, to be able to develop innovative and attractive learning media according to student characteristics, to improve the quality of learning.

Based on this explanation, this research is feasible to be carried out to develop learning media in the form of scientific comic media based on local cultural wisdom to improve high-level thinking skills in grade IV SDN 01 Sambirejo Jumantono Karanganyar.

\section{LITERATURE REVIEW}

\subsection{HOTS (Higher-Order Thinking Skill)}

\subsubsection{Definition of HOTS}

Thomas and Throne revealed that HOTS (Higher-Order Thinking Skill) is a framework of thinking that has a higher level than remembering facts or recalling things. HOTS also demands to do something about the facts. Lewis \& Smith states that HOTS is a way for students to receive information and then expand the information received to find out possible answers to that information.

HOTS is also defined as the ability to solve problems (problem-solving), critical thinking skills (Critical Thinking), creative thinking (Creative Thinking), the ability to argue (Reasoning), and the ability to make decisions (Decision Making). HOTS has important competencies in the modern world that must be possessed by students.

One way to improve students' higher-order thinking skills is when students are faced with a problem that they have not encountered before, this is where the high level thinking process of students will be trained. If learning at school does not equip students to be skilled at high-level thinking, it will produce graduates who are not ready to overcome various problems in the real world. HOTS is related to the ability to solve problems, think critically, and think creatively.

Based on Bloom's Taxonomy Revised by Anderson and Krathwohl, the goal of learning is divided into two dimensions, namely the cognitive dimension and the dimension of knowledge. In the cognitive dimension, HOTS consists of the process of analyzing, evaluating, and creating. Whereas the HOTS knowledge dimension includes conceptual knowledge, procedural knowledge, and metacognitive knowledge.

Applying the revised bloom taxonomy at the level of HOTS (Higher-Order Thinking Skill), students can first do learning activities in remembering, understanding, and applying, and then students can do activities at the HOTS level.

High-level thinking skills related to cognitive processes. Cognitive processes are categorized into two aspects, namely aspects of critical thinking and aspects of creative thinking. The critical thinking aspect is an aspect based on the available evidence. Cognitive aspects of critical thinking include analyzing (C4) and evaluating (C5). While the aspect of creative thinking is the process of producing a product, idea, or new idea that has never existed. The cognitive process aspect of creative thinking is creating (C6).

Table 1. The description of HOTS is based on its relevance and dimensions

\begin{tabular}{|c|c|c|c|c|}
\hline Aspect & $\begin{array}{l}\text { Dimension } \\
\text { Process } \\
\text { Cognitive }\end{array}$ & $\begin{array}{l}\text { Cognitive } \\
\text { Process Sub } \\
\text { Dimensions }\end{array}$ & $\begin{array}{c}\text { Dimension } \\
\text { Knowledge }\end{array}$ & HOTS \\
\hline \multirow{5}{*}{$\begin{array}{l}\text { Critical } \\
\text { thinkin }\end{array}$} & \multirow{3}{*}{ Analyze } & Distinguish & \multirow{8}{*}{$\begin{array}{l}\text { Procedural } \\
\text { Conceptual } \\
\text { Metacogniti } \\
\text { on }\end{array}$} & $\begin{array}{l}\text { Differentiating concepts } \\
\text { Differentiating Procedures } \\
\text { Differentiating } \\
\text { metacognition }\end{array}$ \\
\hline & & Organize & & $\begin{array}{l}\text { Organizing concepts } \\
\text { Organizing procedures } \\
\text { Organizing } \\
\text { metacognition }\end{array}$ \\
\hline & & Attributing & & $\begin{array}{l}\text { Contributing concepts } \\
\text { Attributing Attributing } \\
\text { procedure } \\
\text { metacognition }\end{array}$ \\
\hline & \multirow{2}{*}{ Evaluate } & Check & & $\begin{array}{l}\text { Check concepts Check } \\
\text { procedure } \\
\text { Check metacognition }\end{array}$ \\
\hline & & Criticize & & $\begin{array}{l}\text { Criticize concepts } \\
\text { Criticize the procedure } \\
\text { Criticize metacognition }\end{array}$ \\
\hline \multirow{3}{*}{$\begin{array}{l}\text { Creative } \\
\text { thinking }\end{array}$} & \multirow{3}{*}{ Create } & Formulate & & $\begin{array}{l}\text { Formulate concepts } \\
\text { Formulate procedure } \\
\text { Formulate } \\
\text { metacognition }\end{array}$ \\
\hline & & Plan & & $\begin{array}{l}\text { Plan a concept Planning } \\
\text { procedures Planning } \\
\text { metacognition }\end{array}$ \\
\hline & & Produce & & $\begin{array}{l}\text { Producing concepts } \\
\text { Producing procedure } \\
\text { Producing metacognition }\end{array}$ \\
\hline
\end{tabular}

\subsubsection{HOTS Characteristics}

HOTS characteristics as revealed by Resnick include non-algorithmic, complex, multiple solutions (many solutions), involving variations in decision making and interpretation, applying multiple criteria (many criteria), and being effortful 
(requires a lot of effort). Characteristics of higherorder thinking skills also include critical thinking and creative thinking. Critical and creative thinking are two very basic human abilities because both can encourage a person to always look at every problem faced critically and, try to find answers creatively so that a new thing that is better and useful for his life is obtained.

The following describes the characteristics of HOTS questions.

\subsubsection{Measuring HOTS} of:

Creativity solves problems in HOTS, consisting

a. the ability to solve problems that are not familiar

b. with the ability to evaluate the strategies used to solve problems from a variety of different perspectives

c. find new settlement models that are different from previous ways.

Higher-order thinking skills can be trained in the learning process in the classroom. Therefore, so that students can think at a high level, the learning process also provides space for students to find the concept of activity-based knowledge. Activities in learning can encourage students to build creativity and critical thinking.

\subsubsection{Contextually based problems}

HOTS questions are assessments based on real situations in daily life, where students are expected to be able to apply learning concepts in class to solve problems. Contextual problems faced by the world community today are related to the environment, health, earth, and space, as well as the use of science and technology in various aspects of life. This sense also includes how students' skills to connect (relate), interpret (interpreted), apply (apply), and integrate (integrate) science in learning in class to solve problems in real contexts.

\subsubsection{Different forms of questions}

Problems or problems that can trigger high-level thinking skills are complex problems that are not solved with simple memory, but require the application of certain strategies and processes. Highlevel skills can be measured using tests.

Three formats can be used to measure HOTS, namely:

a. Choosing an answer (multiple-choice questions, matching questions)

b. Generating (questions with short answers, essays, and performance)

c. Explain (give reasons for a choice or answer to a question)

Along with the implementation of the 2013 curriculum, it is hoped that there will be a paradigm shift in the implementation of learning. Learning that was initially centered on teachers (teacher-centered) turned into student-centered (student-centered). Mental skills were initially determined based on Bloom's Taxonomy which categorizes various levels of thought, from the lowest to the highest, namely: knowledge; understanding; application; analysis; synthesis, and evaluation. Way of thinking at a higher level than memorizing or retelling something that is told by others. HOTS is the ultimate goal achieved through approaches, processes, and learning methods. The mistake of understanding the concept of HOTS will have an impact on learning model errors that are increasingly ineffective and unproductive. If the learning process is designed to reach a high level of thinking, the learning objectives can adopt the recommended verbs.

The concept of Bloom's Taxonomy to determine the learning process that students will go through. Therefore, to improve the quality of education, not only increase the level of difficulty in using the HOTS concept but as a whole starting from the curriculum. For example, by reducing material and increasing reflection and project-based learning processes. Thinking is done in two forms: words and picture. Words and pictured are symbols that encourage the human brain to remember and delve into their meaning in thinking activities. The worded is a symbol of what we hear and read, while a picture represents what we see and imagine. There are three main types of intelligence and thinking ability: analytical, creative, and practical

\subsection{Science comic}

Science-comic is an illustrated story that contains knowledge aimed at conveying information and achieving aesthetic responses from readers.

Comics as a medium have a very important role in learning. Comics can be used as a learning support tool that motivates students to better understand the material because comics stimulate students to read and understand what they have read. However, the use of comics as a medium for learning must also look at the characteristics that exist in students. Adjustments in learning comics are focused on the use of language, images, and content or material that is tailored to the learning material and student characteristics. This is because comics are reading that are not only intended for students or children, but also for adults so that making comics as a learning medium must be adjusted to the age level and characteristics of the users or those who will use the comic. 
The researcher determines the criteria for good comics for fourth-grade elementary school students which include, (1) display aspects; (2) linguistic aspects; (3) content or content aspects; and (4) completeness aspect. The display aspect includes everything from the size, cover, color selection, and the suitability of the image to the theme taken. Linguistic aspects include spelling, word selection, and legibility of the letters used. The content or content aspect includes the contents contained in the comics, the suitability of the content with the level of student development, as well as the suitability of the material with KI and KD Curriculum 2013. Then the completeness aspect includes the availability of useful parts to facilitate the use of comic media. These aspects are then used as a reference for developing an expert validator assessment instrument.

the practicality of a media can not only be judged on one side of its usefulness or ease. But it must cover both. A media will be practical to use if it is able to provide convenience and benefit to its users. Based on this, the researcher determined the practicality criteria for the IPA comic book media, including the appearance aspects that were tailored to the needs and development of students, ease of use, clutter and depth of material, material coverage, and availability of complementary instruments such as instructions for use and a table of contents. can make it easier for users. These criteria are then used as a reference in the preparation of the media practicality questionnaire instrument.

The criteria for the effectiveness of the science comic media developed are if the two measured variables, namely higher-order thinking skills and the character of caring for living things in students, can increase. If the application of comic science media cannot increase the measured variables, then the media is declared ineffective.

\subsection{Local Culture}

Local culture is a cultural characteristic of a local community group that is built naturally, sourced from religious values, customs, ancestral advice, or local culture that is bound by the awareness and identity of cultural unity to adapt to the environment surrounding.

Punakawan is a unique type of character in Indonesian shadow theatre. They generally represent the commoners. The characters of Punakawan indicate various roles, such as the warrior advisors, the entertainers, social critics, and clowns, a further source of truth and wisdom. In Javanese wayang, the punakawan characters consist of Semar, Gareng, Bagong, and Petruk.

Punakawan puppet characters were chosen because they have the characteristics and behavior that are by following the character of the local wisdom of the Indonesian people. Even though his status is only a servant, he has noble characteristics. helpful, diligent, (3) Gareng Confident, does not like to see bad things, (4) Bagong Likes to joke, naive, honest. In puppetry, the characters Semar, Petruk, Gareng, and Bagong have an appearance that is not suitable for children. This can lead to decreased levels of children's attention. For this reason, the researcher redesigned the appearance of the characters Semar, Petruk, Gareng, and Bagong without eliminating the characteristics of each character. The designs of the four characters are made attractive and adapted to the children's characters.

\section{METHODS}

This research is research and developed by Borg and Gall. This research will development a product in the form of a comic based on local wisdom whose content is adjusted to the theme of caring for living things, let's love the environment with steps following the Borg and Gall development model, but limited to the fifth stage, namely: (1) research and collection data; conducted observations and interviews with grade IV teachers at SD N 01 Sambirejo, Jumantono District, Karanganyar Regency, with the results of the teacher suggesting that researchers make learning media that can be used to deliver the latest curriculum material better in accordance with the area of residence (2) planning; making media designs based on local wisdom according to the characteristics of students (3) developing a product draft; preparing material from the teacher's book and fourth grade student's book with the theme of caring for living things, determining the punokawan figures as characters in comics, designing dialogues to be used according to the theme of caring for living things, sub-theme of let's love the environment, making comic designs based on local wisdom with materials easy-to-find and easy-to-use applications, here the researcher uses the Corel Draw application, Adobe Photoshop CS3 and Adobe Illustrator CS6, (4) initial field trials; tested in SDN 01 Sambirejo, Jumantono Subdistrict, Karanganyar Regency in grade IV, totaling 33 students, (5) revising the trial results; based on the advice given by media experts and material experts through an assessment questionnaire with the following qualifications:

Table 2. Level of Achievement and Qualification

\begin{tabular}{cl}
\hline Assessment & Criteria for Interpretation \\
\hline $81 \%-100 \%$ & Very feasible \\
$61 \%-80 \%$ & Eligible \\
$41 \%-60 \%$ & Fairly feasible \\
$21 \%-40 \%$ & Not feasible \\
$0 \%-20 \%$ & Absolutely not \\
\hline
\end{tabular}




\section{DISCUSSION AND IMPLICATION}

Comic media based on local cultural wisdom is developed based on research and development steps according to the model proposed by Borg and Gall which consists of 10 stages, but researchers limit research to only stage 5 . Comic media based on local cultural wisdom is a learning medium. which was developed according to local cultural wisdom that exists in Karanganyar Regency so that its use is specifically for elementary schools in Karanganyar Regency according to the applicable curriculum, namely the 2013 curriculum for the theme of peduli terhadap makhluk hidup the sub-theme of ayo cintai lingkungan the environment of fourth-grade elementary school students. Researchers designed every element in learning starting from learning a syntax to media display according to the questionnaire needs of students and teachers. Comic media based on local cultural wisdom can make students happy and active in participating in learning, this can be seen from the responses of students filled in through student assessment questionnaires on the media after participating in learning. The development of comic media is increasingly varied with the existence of a "let's have an adventure" section which contains questions with the presentation of the game and a certificate of appreciation at the end of the page to increase the interest of students to be more active in participating in learning. The teacher's response that comic media can involve all students to participate in learning in a fun way, especially in winning award stars, makes learning efficient and effective.

The main implication of this research is that comics are an effective learning medium to improve the teaching and learning process, thus making it interesting to learn. Students can hone their thinking skills, because they will become active, besides that students and teachers can achieve learning goals effectively and easily. The percentage of student active participation was $94.27 \%$ for limited trials and the average student active participation in field trials was $95.94 \%$. Student learning outcomes showed $87.75 \%$ of classical completeness data for small-scale trials, while large-scale trials obtained an average percentage of $88.37 \%$, and were categorized as very good. Therefore, the gravitational comic media developed were declared valid, practical, and effective. In short, graffiti comic media is useful for the science learning process in grade $\mathrm{V}$ Elementary School. There is a relationship between Ntobuo's research and research to be conducted by researchers. This relationship is the use of comic media and content that elevates local culture.

\section{CONCLUSION}

The application of science-comic media with punokawan characters can improve the ability to think at a higher level because it provides an opportunity for students to develop imagination and find identity by acting as real characters and situations in life with the help of sequential science-comic pictures.

The author suggests is that the quality of learning increases, namely: (1) for teachers, teachers should intensively condition students, train and prepare students to perform demonstrations so that students are more confident and courageous, provide motivation, direction, and appreciation for students to be more active when discuss and ask questions; (2) for students, students must be more focused, active, creative, confident, brave and disciplined during the learning process; (3) for schools, schools should support and facilitate teachers in implementing innovative learning; (4) for further researchers, Through the development of Science-comic interactive media based on local cultural wisdom it is also expected to produce students who are scientifically strong while still loving and proud of their own culture.

\section{REFERENCES}

[1] A.A Putri, Sri Wahyuni, D. A Putra (2017). Utilizing of Comic and Jember's Local Wisdom as Integrated Science Learning Materials. International Journal of Social Science and Humanity, Vol. 7, No. 1, January 2017

[2] Amaruddin, H., Haryadi, M., \& Setianingsih, E. S. (2018). Development of comic based on local wisdom as learning media for primary school. In F. Ahmadi \& Masturi (Eds.), Proceedings of the International Conference on Science and Education and Technology 2018 (ISET 2018) (pp. 233-236), Atlantis Press. https://doi.org/10.2991/iset-18.2018.49

[3] Arroio, A., Karen, C., Teresa, C.B., Khyslaynyk, Sousa, D., Santos, P.M \&Souza, D.D. 2013. Introducing Comics As An Alternative Scientific Narrative In Chemistry Teaching. BatıAnadoluEğitimBilimleriDergisi (BAED), 4 (8): 1-14.

[4] Arsyad, Azhar. (2016). Media Pembelajaran. Jakarta: PT Raja Grafindo Persada.

[5] Buchori, A., \& Setyawati, R. D. (2015). Development learning model of character education through e-comic in elementary school. International Journal of Education and Research, 3(9), 369-386. 
[6] Candra D (2018). Implementation Of Learning Comic Fabel Media As Environmental Education Supplements Student In Elementary School. The 3 rd International Conference on Basic Education and Early Childhood June 30, 2018, Indonesia University of Education, Serang Campus

[7] Damopoli, S R Rahman (2019). The effect of STAD learning model and science comics on cognitive students achievement. International Conference on Mathematics and Science Education (ICMScE 2018). IOP Conf. Series: Journal of Physics: Conf. Series 1157 (2019) 022008 IOP Publishing doi:10.1088/1742-6596/1157/2/022008

[8]

$$
\text { Daryanto. (2013). Media }
$$

Pembelajaran. Yogyakarta: Gava Media.

[9] Depdiknas. (2008). Kamus Besar Bahasa Indonesia Pusat Bahasa Edisi Keempat. Jakarta: PT. Gramedia.

[10] DK Murti, Desy Ningrum, Gunarhadi.(2020). Development of Educational comic with local wisdom to Foster Morality of Elementary School Students: A Need analysis. International Journal of Educational Methodology, v6 n2 p337-334 2020. ISSN:2469-9632. http://www.ijem.com/

[11] DY Saputri, Rukayah, Mintasih Indriayu (2018). Integrating Game-based Interactive Media as Instructional Media: Students' Response. Journal of Education and Learning (EduLearn) Vol.12, No.4, November 2018, pp. 638 643 ISSN: 20899823 DOI: 10.11591/edulearn.v12i4.8290.

[12] Espada, W. J. G. 2003. Integrating Physical Science and The Graphic Arts With Scientifically Accurate Comic Strips: Rationale, Description, And Implementation. RevistaElectrónica de Enseñanza de lasCiencias, 2(1): 58-66.

[13] Fanani, A., \& Kusmaharti, D. (2018). Pengembangan pembelajaran berbasis HOTS (higher order thinking skill) di sekolah dasar kelas $V$. Jurnal Pendidikan Dasar, 9(1), 1-11. doi: 10.21009/JPD.091.01.

http://journal.unj.ac.id/unj/index.php/jpd/article/v iew/JPD.91.01

[14] Hendra S, Evita A, Jamiatul S (2019). Development of E-Modules Based on Local Wisdom in Central Learning Model at Kindergartens in Jambi City. European Journal of Educational Research Volume 8, Issue 4, 1137 1143. ISSN: 2165-8714 http://www.eu-jer.com/

[15] Hidayah, N., \& Ulva, R. K. (2017). Pengembangan Media Pembelajaran Berbasis Komik Pada Mata Pelajaran Ilmu Pengetahuan Sosial Kelas IV MI
Nurul Hidayah Roworejo Negerikaton Pesawaran. Terampil Jurnal Pendidikan Dan Pembelajaran Dasar, 4(1), 34-46.

[16] H M Saputri (2017). Indonesian Culture-Based Comic For Teaching Young Learners In Indonesia. The 2nd TEYLIN International Conference Proceedings April 2017

[17] Khiyarusoleh, U., Ardiyansyah, A., \& Wilujeng, I. (2017). Developing comic-based busapaksa to elementary school students. In Saefurrohman, M. Winda, B. A. Suady, Suhandini, \& A. S. Dadari (Eds.), Proceedings of the 4th Asia Pacific Education Conference (AECON 2017) (pp. 309312), Atlantis Press. https://doi.org/10.2991/aecon-17.2017.57

[18] Krishnan, S., \& Othman, K. (2013). The Effectiveness Of Using Comic To Increase Pupils' Achievements And Higher Order Thinking Skills In Science. International Journal of English and Education, 5(3), 281-293.

[19] Kurniawati, A. A., Wahyuni, S., \& Putra, P. D. (2017). Utilizing of comic and Jember's local wisdom as integrated science learning materials. International Journal of Social Science and Humanity, 7(1),47-51. https://doi.org/10.18178/ijssh.2017.7.1.793

[20] Meijayanti. (2015). Pengembangan E-Comic Berbasis CTL. Yogyakarta: Universitas Negeri Yogakarta.

[21] Ningrum, dkk. (2007). Peran Tokoh Punakawan dalam Wayang Kulit sebagai Media Penanaman Karakter di Desa Bendosewu Kecamatan Talun Kabupaten Blitar. Malang: Universitas Malang

[22] Ntobuo, N. E., Arbie, A., \& Amali, L. N. (2018). The development of gravity comic learning media based on gorontalo culture. Jurnal Pendidikan IPA Indonesia, 7(2), 246-251. https://doi.org/10.15294/jpii.v7i2.14344

[23] Nurdinah Hanifah. (2019). Pengembangan Instrumen Penilaian Higher Order Thinking Skill (HOTS) di Sekolah Dasar. Current Research in Education: Conference Series Journal Vol. 1 No. 1 , Issue 5. https://ejournal.upi.edu/index.php/crecs/article/vi ew/14286/pdf

[24] Nur AH, dkk (2020). Exploring the Implementation of Local Wisdom-Based

Character Education among Indonesian Higher Education Students. International Journal of Instruction April 2020. Vol.13, No. 2 e-ISSN: 1308-1470. www.e-iji.net p-ISSN : 1694-609X pp 
179-198, Received : 24/02/2019, Revision: 01/11/2019, Accepted: 06/11/2019, onlineFirst: $11 / 01 / 2020$

[25] Nurul P, Umar A A H (2019). Lokal Wisdom Based EFL Teaching: Internalizing The Values Of Local Culture To Millenial Learners. The 2nd International Conference on English Language Teaching and Learning (2nd ICON-ELTL) 2019

[26] P. D. A. Putra and M. Iqbal, "Implementation of digital comic to improve creative thinking ability in integrated science study," presented at International Conference on Mathematics, Science, and Education (ICMSE), Semarang, May $7-8,2014$

[27] Ratna S dkk(2017). Pengembangan Media Komik Berbasis Kaearifan Lokal pada Pembelajaran Tematik Kelas VI SD. http://prosiding.upgris.ac.id/index.php/PGSD17/ PGSD2017/paper/viewFile/2713/2643

[28] Rina, N., Suminar, J. R., Damayani, N. A., \& Hafiar, H. (2020). Character education based on digital comic media. International Journal of Interactive Mobile Technologies (iJIM), 14(03), 107-127.

https://doi.org/10.3991/ijim.v14i03.12111

[29] Saputro, H. B., \& Soeharto, S. (2015). Pengembangan media komik berbasis pendidikan karakter pada pembelajaran tematik-integratif kelas IV SD [Development of comic media based on character education in the thematic-integrative learning of grade IV elementary school]. Prima Edukasia Journal /Jurnal Prima Edukasia, 3(1), 61-72. https://doi.org/10.21831/jpe.v3i1.4065

[30] Tatalovic, M. 2009. Science comic as Tools for Science Education and Communication: a Brief, Exploratory Study. Journal of Science Communication, 8 (4): 1-16.Tersedia di http://jcom.sissa.it/archive/A02.pdf
[31] T. G. Morrison, G. Bryan, and G. W. Chilcoat, "Using student -generated comic books in the classroom," Journal of Adolescent and Adult Literacy, vol. 45, no. 8, pp. 758-767, May 2002.

[32] Yulianda, A., Ambarita, B., \& Ansari, K. (2019). The feasibility of comic media on narrative texts based on local wisdom in vii grade student of junior high school (smpn) 3 kotapinang. Budapest International Research and Critics in Linguistics and Education (BirLE) Journal, 2(3), 147-163. https://doi.org/10.33258/birle.v2i3.369.

[33] Wardani EK (2017). The Folklore Comics Media for Learning Indonesian as a Foreign Language. Advances in Social Science, Education and Humanities Research, volume 253. 3rd Asian Education Symposium (AES 2018) https://www.atlantis-press.com/proceedings/aes$18 / 55917391$

[34] Widana, Wayan, Modul Penyusunan Soal Higher Order Thingking Skill (Hots). Jakarta: Direktorat Pembinaan Sma, Direktorat Jendral Pendidikan Dasar Dan Menengah, Departemen Pendidikan Dan Kebudayaan, 2017.

[35] Wiji , K (2018). A Need Analysis of Developing HOTS-based Interactive Multimedia. International Conference on Educational Research and Innovation (ICERI 2018) Advance in social science, Education ang Humanities Research (ASSEHR), Volume 330

[36] W Wiana (2018). Interactive Multimedia-Based Animation: A Study of Effectiveness on Fashion Design Technology Learning. The 2nd International Joint Conference on Science and Technology (IJCST) 2017. IOP Publishing IOP Conf. Series: Journal of Physics: Conf. Series 953 (2018) 012024. doi:10.1088/1742$6596 / 953 / 1 / 012024$ 